\title{
APA YANG MEMPENGARUHI TINGKAT STRES ANDA? KAJIAN TINGKAT STRES WARGA MALANG DI CFD JALAN IJEN DITINJAU DARI TIPE KEPRIBADIAN A DAN B
}

\author{
Essha Paulina Kristanti, Rachmawati
}

\section{* Corresponding Author:}

Universitas Wisnuwardhana Malang Email:

esshakristanti@gmail.com

Rachma.widyantoro@gmail.com

\begin{abstract}
Abstrak. Penelitian bertujuan melihat tingkat stres warga kota Malang di CFD ditinjau dari tipe kepribadian A dan B, menggunakan metode penelitian kuantitatif dengan jenis komparatif. Hasil uji Anova menunjukkan F-reg sebesar 1.997 lebih kecil dibandingkan dengan F-table 1\% sebesar 6.90 maupun F-table 5\% sebesar 3.94. Nilai p sebesar 0.119 lebih besar daripada $\mathrm{p}=0.05$, dinyatakan tidak signifikan, menunjukkan tidak ada perbedaan tingkat stres warga Malang yang datang di CFD ditinjau dari tipe kepribadian A dan B, pada taraf kepercayaan 95\%. Faktor kemampuan individu mempersepsi stressor dan bagaimana kemampuan coping stres individu menjadi faktor yang lebih dominan dalam menentukan tingkat stres seseorang. Stres tinggi dialami oleh individu dengan kepribadian A dengan pola perilaku tipe A yang tinggi (tipe A1), sedangkan pada tipe kepribadian yang lain (A2, AB, B2) tidak ada perbedaan yang signifikan karena rentangnya tingkat stresnya beragam.
\end{abstract}

Kata Kunci: Kepribadian A dan B; Stres: CFD

\begin{abstract}
The study aims to look the stress level of Malang citizens in CFD in terms of personality type $A$ and $B$, using quantitative research methods with comparative types. Anova test results showed an F-reg of 1,997 was smaller than an F-table of $1 \%$ of 6.90 and an F-table of 5\% of 3.94. The $p$ value of 0.119 is greater than $p=0.05$, stated to be insignificant, indicating no difference in the level of stress of Malang citizens who come in CFD in terms of personality types $A$ and $B$, at a $95 \%$ confidence level. Factors on the ability of individuals to perceive stressors and how coping abilities of individual handle the stressors, become more dominant factors in determining a person's stress level. High stress level is experienced by individuals with personality $A$ with high type A behavior patterns (type A1), whereas in other personality types $(A 2, A B, B 2)$ there is no significant difference because the range of stress levels varies.
\end{abstract}

Keyword: Personality type A and B; Stress; CFD

\section{PENDAHULUAN}

Kota Malang merupakan salah satu kota yang sedang berkembang dengan pesat dan terletak di Provinsi Jawa Timur Indonesia. Urbanisasi terus berlansung dan kebutuhan masyarakat akan perumahan meningkat diluar kemampuan pemerintah, sementara tingkat ekonomi urbanis sangat terbatas.

Banyaknya pendatang dengan alasan yang beragam tersebut menjadikan Kota Malang semakin padat dan majemuk, sehingga dapat dimungkinkan munculnya konflik atau kesulitan hidup yang harus dijalani oleh warga Malang.
Konflik dan kesulitan hidup yang dirasa tidak dapat teratasi dapat menimbulkan stres bagi beberapa orang. Jika individu mempersepsi suatu kondisi menyebabkan stres, hal ini dapat menimbulkan reaksi emosional atau kebangunan emosional (emotional arousal) terhadap situasi hidup yang menekan.

Munculnya stres dapat disebabkan oleh adanya berbagai sumber stres, diantaranya: kepribadian, lingkungan,dan interaksi antara kepribadian dan lingkungan. Ada beberapa faktor yang dapat mempengaruhi stres seseorang menurut Santrock (2003), antara lain: fak- 
tor lingkungan, faktor kepribadian, dan faktor kognitif. Faktor Lingkungan menurut Santrock antara lain: a) Beban yang Terlalu Berat, Konflik, dan Frustasi. Istilah yang sering digunakan untuk beban yang terlalu berat adalah burnout, perasaan tidak berdaya, tidak memiliki harapan, yang disebabkan oleh stres akibat pekerjaan yang sangat berat. Burnout membuat penderitanya merasa sangat kelelahan secara fisik maupun emosional; dan b) Kejadian Besar dalam Hidup dan Gangguan Sehari-hari. Kehidupan sehari- hari dapat menjadi penyebab stres seperti halnya kejadian besar dalam hidup. Tinggal dengan keluarga yang mengalami ketegangan dan hidup dalam kemiskinan bukanlah sesuatu yang dapat dianggap sebagai kejadian besar dalam hidup seorang remaja, namun kejadian sehari- hari yang dialami remaja dalam kondisi kehidupan seperti itu dapat menumpuk sehingga menimbulkan kehidupan yang sangat penuh dengan stres, dan pada akhirnya remaja akan mengalami gangguan psikologis atau penyakit.

Faktor Kepribadian, lebih terfokus membahas tentang pola tingkah laku Tipe A. Pola tingkah laku Tipe A (type A Behavior pattern) yang dimaksud oleh Santrock merupakan sekelompok karakteristik seperti rasa kompetitif yang berlebihan, kemauan keras, tidak sabar, mudah marah, dan sikap bermusuhanyang dianggap berhubungan dengan masalah jantung. Individu yang bermusuhan dan parah sering diberi "reaktor panas", yang berarti mereka memiliki reaksi fisiologis yang kuat terhadap stres-detak jantungnya meningkat, pernafasannya menjadi semakin cepat, dan otot-ototnya menegang, yang pada akhirnya dapat mengakibatkan penyakit jantung.

Sedangkan, faktor kognitif lebih mengarah pada penilaian kognitif. Penilaian Kognitif adalah istilah yang digunakan Lazarus untuk menggambarkan interpretasi individu terhadap kejadian- kejadian dalam hidup mereka sebagai sesuatu yang berbahaya, mengancam, atau menantang dan keyakinan mereka apakah mereka memiliki kemampuan untuk menghadapi suatu kejadian dengan efektif. Penilaian kognitif akan mempengaruhi reaksi seseorang terhadap stressor.

Menurut Atkinson dkk (2010) peristiwa yang tidak dapat dikendalikan dan tidak dapat diprediksi, atau yang menantang pandangan kita terhadap diri sendiri cenderung dirasakan sebagai stres. Sebagian orang tampaknya lebih sering menilai suatu peristiwa dirasakan sebagai stres dibandingkan orang lain, dan dengan demikian mengalami respon stres terhadap peristiwa tersebut. Salah satu pola atau gaya kepribadian yang banyak mendapatkan perha- tian adalah pola tipe A.

Jika individu yang memiliki kepribadian A terpapar dengan situasi yang penuh stres, sebagian besar individu dengan pola perilaku tipe A akan merespon dengan munculnya perasaan marah, tersinggung, dan tegang. Subyek yang memiliki skor tinggi pada permusuhan sebagai suatu sifat menunjukkan peningkatan tekanan darah, denyut jantung, dan sekresi hormon stres yang jauh lebih tinggi dibandingkan subyek dengan skor permusuhan yang rendah (Suarez \& Williams, 1989 dalam dalam Atkinson dkk, 2010). Hasil yang sama ditemukan jika subyek tipe A dibandingkan dengan subyek tipe B (Manuck \& Kranz, 1987 dalam Atkinson dkk, 2010). Sistem syaraf simpatis individu yang bersikap bermusuhan dan atau tipe A tampaknya hiper-responsif terhadap situasi terhadap stres.

Sejalan dengan ini, Friedman \& Rosenman (1974), Kiev \& Kohn (1979), serta Cooper, dkk. (1988) (dalam Wijono: 2006) menemukan bahwa sumber stres adalah kepribadian tipe A. Temuan berikutnya menunjukkan bahwa sumber stres kerja adalah interaksi hubungan yang tidak harmonis antara individu yang berkepribadian tipe A dan lingkungan kerjanya dalam organisasi, sehingga menimbulkan stres kerja (Ivancevich, Matteson \& Preston, 1982; Hamel \& Bracken, 1986, dalam Kirkcaldy, dkk.,

2000 dalam Wijono: 2006). Sejumlah penelitian yang dilakukan oleh para peneliti di atas menegaskan bahwa sumber stres adalah individu yang berkepribadian tipe A dan interaksi antara kepribadian danlingkungan. Hasil yang sama ditemukan jika subyek tipe A dibandingkan dengan subyek tipe B (Manuck \& Kranz, 1987 dalam Atkinson dkk, 2010). Sistem syaraf simpatis individu yang bersikap bermusuhan dan atau tipe A tampaknya hiper-responsif terhadap situasi terhadap stres.

Salah satu usaha untuk mengatasi stres yang biasa dilakukan masyarakat adalah mencari tempat yang menyediakan hiburan agar dapat melepas kepenatan yang disebabkan oleh stres. Salah satu yang banyak di datangi oleh warga Malang untuk berkumpul dan melepas kepenatan adalah CFD yang berlokasi di Jalan Ijen Malang. Car Free Day atau CFD (dalam malang-guidance.com, 2017) merupakan kegiatan rutin warga Malang raya setiap hari minggu pagi untuk berkumpul bersama di satu tempat tanpa kendaraan bermotor untuk bersenang-senang menikmati suasana dan hawa Kota kita tercinta Kota Malang.

Berdasarkan latar belakang di atas, penulis secara umum ingin mengetahui tingkat stres warga Malang di CFD Jalan Ijen jika ditinjau dari 
Pola Kepribadian A dan B.

\section{METODE}

Variabel dalam penelitian ini adalah tingkat stres sebagai variabel terikat dan pola Kepribadian A dan B sebagai variabel bebas.

Secara operasional, Stres adalah penilaian individu terhadap stimulus lingkungan yang dihadapi dan dinilai sebagai sesuatu yang membebani, membahayakan kesejahteraan atau rasa aman karena melebihi kemampuan yang dimiliki, yang diukur menggunakan skala adaptasi dari PSS (Perceived Stress Scale).

Tipe Kepribadian A dan B adalah pola perilaku khas yang dimiliki individu. Individu yang menunjukkan pola perilaku tipe A sangat kompetitif dan berorientasi pada pencapaian. Sedangkan, individu yang memiliki pola perilaku tipe $B$ sangat santai dan tenang dalam menghadapi pencapaian. Pengukura tipe kepribadian menggunakan The Glazer-Stress Control Lifestyle Questionnaire yang membagi kelompok kepribadian menjadi A1, A2, AB, B1, dan B2.

Desain penelitian yang digunakan adalah penelitian kuantitatif yang lebih menekankan pada aspek pengukuran secara objektif terhadap fenomena sosial. Sedangkan, jenis penelitian yang yang digunakan adalah metode komparatif.

Karakteristik populasi yang akan menjadi subyek penelitian adalah: (a) Warga Malang yang datang ke CFD, dan (b) Usia 15-55 tahun. Teknik sampling yang digunakan dalam penelitian ini adalah Sampling Insidental. Sampling Insidental adalah teknik penentuan sampel berdasarkan kebetulan, yaitu siapa saja yang secara kebetulan atau insidental bertemu dengan peneliti dapat digunakan sebagai sampel, bila dipandang orang yang kebetulan di temui cocok sebagai sumber data. Metode pengumpulan data menggunakan dua skala untuk mengukur tingkat stres dan tipe kepribadian A dan B.

\section{Skala Stres}

Skala stres yang digunakan oleh penulis adalah skala adaptasi dari PSS (Perceived Stress Scale) yang dikembangkan oleh Sheldon Cohen (Cohen dkk, 1983). PSS digunakan untuk mengukur sejauh mana situasi dalam kehidupan seseorang dinilai sebagai stres. Aitem dirancang untuk mengetahui bagaimana responden memandang atau menilai kejadian tak terduga, tak terkendali, dan kelebihan beban dalam kehidupan mereka. Skala juga mencakup sejumlah pertanyaan langsung tentang tingkat stres yang dialami saat ini.

Skala tersebut terdiri dari sepuluh pertanyaan yang menanyakan tentang perasaan dan pikiran subyek penelitian selama sebulan terakhir tentang sesuatu yang dinilai sebagai stressor. Terdapat lima buah pilihan jawaban, pilihannya adalah sebagai berikut: tidak pernah (0), hampir tidak pernah (1), kadang-kadang (2), sering (3), sangat sering (4); dengan blue print sebagai berikut:

Tabel 1. Blue print Skala Stres (PSS)

\begin{tabular}{ll}
\hline \multicolumn{1}{c}{ Dimensi } & \multicolumn{1}{c}{ Item } \\
Time urgency & $1,2,4,5,6,7,8,11,12,14,15$, \\
& $16,17,19,20$ \\
& $3,9,10,13,18$ \\
\hline Hostility & \\
\hline
\end{tabular}

Dari penjumalah hasil angka yang dilingkari oleh subyek penelitian, kita akan dapat melihat tingkatan stres yang ia miliki, dengan tingkatan sebagai berikut:

a. Tingkat stres rendah dengan skor: 0-7

b. Tingkat stres sedang dengan skor : 8-20

c. Tingkat stres tinggi dengan skor diatas 20

\section{Skala Tipe Kepribadian A dan B}

Skala Pola Perilaku tipe A yang digunakan oleh penulis adalah skala adaptasi dari The Glazer-Stress Control Lifestyle Questionnaire yang dikembangkan oleh Dr. Howard Glazer (dalam Patel, 1989). Skala ini terdapat dua puluh pasang kata sifat atau frase yang dipisahkan oleh tujuh deretan kotak. Masing-masing pasangan frase tersebut telah dipilih untuk mewakili dua jenis perilaku yang kontras dengan nilai antara 1 sampai dengan 7 .

Tabel 2. Blue print The Glazer-Stress Control Lifestyle Questionnaire

\begin{tabular}{lcc}
\hline \multicolumn{1}{c}{ Dimensi } & F & $\underline{\text { UF }}$ \\
\hline $\begin{array}{l}\text { Kejadian tak terduga } \\
\text { Kejadian tak terkend- }\end{array}$ & $\mathbf{1}$ & $\underline{\mathbf{5}}$ \\
$\begin{array}{l}\text { ali } \\
\text { Kelebihan beban da- }\end{array}$ & 3,10 & 7,4 \\
lam hidup & & 8 \\
\hline
\end{tabular}

Nilai dari skala tiap individu merupakan penjumlahan dari nilai jawaban tiap soal, dimana tiap nilai dapat digolongkan pada lima kategori berdasarkan besar jumlah nilainya. Kriteria penilaian The Glazer-Stress Control Lifestyle Questionnaire, adalah: 
1. Jenis A1, memiliki resiko tinggi terkena penyakit jantung, dengan nilai 110-140

2. Jenis A2, rawan terkena penyakit jantung, dengan nilai 80-109

3. Jenis $A B$, merupakan campuran pola $A$ dan B, dengan nilai 60-79

4. Jenis B2, biasanya relaks dan mampu mengatasi stres, dengan nilai 30-59

5. Jenis B1, merupakan non-sifat jantung, dengan nilai 0-29

Hipotesa dalam penelitian ini adalah ada perbedaan tingkat stres warga Malang yang datang di CFD ditinjau dari tipe kepribadian A dan B. Hal ini bertujuan untuk melihat apakah tipe kepribadian memiliki andil dalam menentukan tingkat stres seseorang. Pengujian hipotesa dalam penelitian ini dilakukan dengan menggunakan teknik analisis statistik yang menguji perbedaan rerata antar grup dengan menggunakan SPSS 20.00 yaitu tehnik ANOVA. ANOVA merupakan prosedur uji statistik yang dapat menguji perbedaan lebih dari dua kelompok, dimana kelompok dalam penelitian ini terbagi menjadi 5, yaitu tipe kepribadian A1, A2, AB, B1, DAN B2, sesuai dengan pembagian pada skala tipe kepribadian A dan B.

\section{HASIL DAN PEMBAHASAN Hasil}

Penggambilan data untuk penelitian dilakukan peneliti bersama tim saat berlangsunganya CDF pada bulan Januari 2020 di minggu pertama, dan berhasil mengumpulkan data sebanyak 116 subyek yang mengisi skala tipe kepribadian dan skala stres dalam keadaan yang lengkap dan datanya dapat diolah. Pengolahan data menggunakan bantuan Komputasi Seri Program Statistik (SPS-20) Analisa Varians. Dari hasil analisa data diperoleh hasil sebagai berikut:

Tabel 3. Hasi uji ANOVA

\begin{tabular}{|l|l|l|l|l|l|}
\hline Stress & $\begin{array}{l}\text { Sum of } \\
\text { Square }\end{array}$ & $\mathrm{df}$ & $\begin{array}{l}\text { Mean } \\
\text { Square }\end{array}$ & $\mathrm{F}$ & Sig. \\
\hline $\begin{array}{l}\text { Between } \\
\text { Groups } \\
\text { Within } \\
\text { Groups }\end{array}$ & 136.818 & 3 & 45.606 & 1.997 & .119 \\
\hline Total & 2558.009 & 112 & 22.839 & & \\
\hline
\end{tabular}

Pada tabel 3 dapat diketahui hasil uji Analisa Varians bahwa F reg sebesar 1.997 lebih kecil dibandingkan dengan $\mathrm{F}$ table $1 \%$ sebesar 6.90 maupun $\mathrm{F}$ table 5\% sebesar 3.94, sehingga dinyatakan tidak signifikan. Nilai p sebesar 0.119 lebih besar daripada $p=0.05$, sehingga juga dinyatakan tidak signifikan, yang artinya tidak ada korelasi antara tipe kepribadian A dan tipe kepribadian B dengan tingkat stress. Dengan demikian hipotesi yang berbunyi "Ada perbedaan tingkat stres warga Malang yang datang di CFD ditinjau dari tipe kepribadian A dan B, ditolak pada taraf kepercayaan $95 \%$.

Tabel 4. Hasil Uji Deskriptif

\begin{tabular}{|l|l|l|l|l|l|l|l|l|}
\hline & & & & \multicolumn{3}{|l|}{$\begin{array}{l}\text { 95\% Confidence } \\
\text { Interval for } \\
\text { Mean }\end{array}$} & & \\
\hline & N & Mean & $\begin{array}{l}\text { Std, } \\
\text { Devi- } \\
\text { ation }\end{array}$ & $\begin{array}{l}\text { Std. } \\
\text { Er- } \\
\text { ror }\end{array}$ & $\begin{array}{l}\text { Lower } \\
\text { Bound }\end{array}$ & $\begin{array}{l}\text { Upper } \\
\text { Bound }\end{array}$ & $\begin{array}{l}\text { Mini- } \\
\text { mum }\end{array}$ & $\begin{array}{l}\text { Maxi- } \\
\text { mum }\end{array}$ \\
\hline B2 & 8 & 18.12 & 3.44 & 1.23 & 15.25 & 21.00 & 21.00 & 24 \\
AB & 48 & 18.23 & 4.58 & 0.66 & 16.89 & 19.56 & 19.56 & 30 \\
A2 & 58 & 18.12 & 5.06 & 0.66 & 16.78 & 19.45 & 19.45 & 29 \\
A1 & 2 & 26.50 & 4.95 & 3.5 & -17.97 & 70.97 & 70.97 & 30 \\
\hline Tot & 116 & 18.31 & 4.84 & 0.45 & 17.42 & 19.2 & 19.20 & 30 \\
\hline
\end{tabular}

Dalam Tabel 4, kita dapat melihat dari 116 subyek penelitian yang merupakan warga Malang dan datang ke CFD pada minggu pertama bulan Januari 2020, menunjukkan bahwa sebagian besar memiliki tipe kepribadian $A B$ dan $A 2$, dimana Kepribadian $A B$ terdapat 48 orang dan Kepribadian A2 sebanyak 58 orang. Kepribadian AB merupakan kepribadian yang memiliki pola kepribadian campuran dari pola perilaku A dan B, sedangkan Kepribadian A2 merupakan kepribadian yang memiliki pola kepribadian A tetapi tidak terlalu ekstrim, baik pola kepribadian dalam pengelolaan waktu dan dan sikap permusuhan.

Data menunjukkan tipe kepribadian A1 memiliki jumlah yang paling sedikit, yaitu 2 orang. Data ini menjadi menarik, karena hal ini menunjukkan bahwa orang-orang tipe kepribadian A yang ekstrim tidak menyukai kegiatan-kegiatan yang membuang-buang waktu seperti berjalan- jalan ke CFD . Mereka menyukai pergerakan yang cepat dan tidak sabaran. Mereka juga tipe orang yang akan sulit untuk duduk-duduk santai atau tidak melakukan apaapa, karena mereka akan merasa bersalah saat beristirahat.

Selain data tentang tipe kepribadian, kita juga dapat melihat dari tabel 4 menunjukkan tentang tingkat stres warga malang yang datang ke CFD, yakni yang paling rendah memiliki skor 4, dimana tergolong tingkat stres yang rendah; dan yang paling tinggi adalah skor 30, yang menunjukkan tingkat stres yang tinggi. Hal ini menunjukkan bahwa tidak ha- 
nya orang yang memiliki tingkat stres yang sedang dan tinggi saja yang datang ke CFD, tetapi juga orang yang tingkat stres rendah atau tidak mengalami stres juga memilih untuk datang ke CFD.

Dari tabel 4 juga menunjukkan bahwa tipe kepribadian B2 memiliki rentang skor stres antara 13-24; tipe kepribadian $\mathrm{AB}$ memiliki rentang skor stres antara 5-30; tipe kepribadian A2 memiliki rentang skor stres antara 4-29; dan tipe kepribadian A1 memiliki rentang skor stres antara 23-30.

Setelah menelaah hasil analisis data yang telah dipaparkan pada hasil penelitian, kita dapat melihat bahwa individu yang pola kepribadian $A$ dan $B$, yang terbagi kelompok menjadi $\mathrm{A} 1$, A2, AB, B1, dan B2; tidak memiliki perbedaan yang signifikan dalam tingkat stres. Hal menunjukkan bahwa hipotesi yang berbunyi "Ada perbedaan tingkat stres warga Malang yang datang di CFD ditinjau dari tipe kepribadian A dan B", ditolak pada taraf kepercayaan $95 \%$.

Hasil penelitian ini tidak sejalan dengan penelitian yang telah dilakukan oleh Suarez \& Williams, 1989 (Atkinson dkk, 2010). Jika individu yang memiliki kepribadian A terpapar dengan situasi yang penuh stres, sebagian besar individu dengan pola perilaku tipe A akan merespon dengan munculnya perasaan marah, tersinggung, dan tegang. Subyek yang memiliki skor tinggi pada permusuhan sebagai suatu sifat menunjukkan peningkatan tekanan darah, denyut jantung, dan sekresi hormon stres yang jauh lebih tinggi dibandingkan subyek dengan skor permusuhan yang rendah.

Hasil yang sama ditemukan jika subyek tipe A dibandingkan dengan subyek tipe B (Manuck \& Kranz, 1987 dalam Atkinson dkk, 2010). Sistem syaraf simpatis individu yang bersikap bermusuhan dan atau tipe A tampaknya hiper-responsif terhadap situasi terhadap stres. Penelitian Wijono (2006) juga menunjukkan bahwa kepribadian tipe A dan peran berpengaruh sekaligus terhadap stres kerja manager madya, dimana pengaruh variabel kepribadian tipe A dan peran sekaligus dengan variabel stres kerja sebesar $33,2 \%$, sedangkan sisanya $66,8 \%$ dipengaruhi oleh variabel lainnya.

Hasil penelitian yang menunjukkan tidak adanya perbedaan yang signifikan dalam tingkat stres pada pola kepribadian A dan B ini mendukung penelitian Nurzulawati (2016) tentang Hubungan antara Kepribadian Tipe A dengan stres kerja pada Guru SMK Muhammadiyah Tegal yang menujukkan hasil bahwa tidak ada hubungan antara tipe kepribadian A dengan stres kerja. Menurut Nurzulawati, stres kerja tidak hanya dipengaruhi oleh kepribadian tipe A saja, tetapi juga dipengaruhi oleh faktor lain, seperti persepsi individu terhadap suatu keadaan atau peristiwa yang terjadi, hal ini juga dapat membuat para guru tidak mengalami stres kerja, karena para guru baru saja mengikuti pelatihan dengan mengisi raport bersama-sama untuk kurikulum terbaru, yaitu kurikulum 13, dan juga penataran bagi para wakil kepala sekolah bagian kurikulum. Hal ini bisa mengurangi stres kerja. Selain itu seseorang dalam merespon stres juga dipengaruhi oleh dukungan sosial.

Penelitian ini juga sejalan dengan penelitian yang dilakukan oleh Migo (2013), yang menyatakan bahwa kepribadian tipe A tidak mempunyai pengaruh terhadap stres kerja. Hal ini dikarenakan individu yang memiliki kepribadian tipe A sangat menyadari akan kekurangan yang dimilikinya dalam menyelesaikan tugas, sehingga dengan kondisi tersebut individu dengan kepribadian tipe A, lebih mempersiapkan diri dalam menghadapi berbagai macam tugas dan tanggung jawab yang besar yang diberikan kepadanya, dengan jalan individu tersebut mengikuti berbagai pelatihan, selalu berusaha bertanya dan berdiskusi dengan orang yang lebih berpengalaman, sehingga dengan hal tersebut membuat kompetensi individu dengan kepribadian tipe A menjadi semakin baik, menjadi selalu siap ketika dihadapkan dengan variasi pekerjaan yang beragam, dan tanggung jawab yang besar, yang diserahkan kepadanya, sehingga tidak mempengaruhi tingkat stres yang individu rasakan sebelumnya.

Hipotesis penelitian ini tidak diterima dapat memiliki beberapa penyebab, yakni: 1) Ada faktor-faktor lain selain pola kepribadian yang memiliki pengaruh lebih besar dalam menentukan pandangan individu terhadap stres; 2 ) Warga Malang yang sedang di CFD merupakan mereka yang sedang jalan-jalan santai, melepaskan kepenatan dan ketegangan sambil berolahraga atau berjalan santai sehingga tingkat stres bisa menurun.

Menurut Perwitasari, dkk (2016) dalam penelitian tentang Faktor-faktor yang mempengaruhi tingkatan stres pada Tenaga Kesehatan di RS Universitas Tanjungpura Pontianak menujukkan bahwa faktor kemampuan individu mempersepsi stressor, faktor intensitas terhadap sitimulus (responden jarang menghadapi stressor yang berat), faktor jumlah stressor yang harus dihadapi dalam waktu yang sama merupakan 3 faktor yang paling besar memiliki pengaruh 
pada tingkatan stres dibandingkan dengan faktor yang lain.

Faktor yang mempengaruhi perbedaan tingkat stres antara satu orang dengan yang lainnya menurut Badeni (2013) adalah sebagai berikut:

1. Persepsi terhadap stressor, merupakan suatu proses yang harus dilalui oleh individu untuk memberikan arti yang bermakna pada lingkungannya

2. Pengalaman dalam menghadapi peristiwa yang menyebabkan stres, individu yang telah memiliki pengalaman dalam menghadapi suatu peristiwa akan membuat individu tersebut memahami dengan apa yang akan dilakukannya untuk menghadapi situasi yang menyebabkan stres

3. Kemampuan memprediksi peristiwa yang menyebabkan stres, merupakanusaha seseorang untuk memprediksi situasi yang dapat menimbulkan stres yang mungkin akan dialami oleh individu dimasa mendatang

4. Jenis kepribadian, individu dengan kepribadian internal locus of control diprediksikan lebih rendah tingkat stresnya ketika menghadapi situasi yang penuh dengan tekanan, dibandingkan dengan individu dengan kepribadian eksternal locus of control.

5. Dukungan sosial, dukungan sosial yang berupa hubungan kerja antara atasan dengan bawahan yang baik dapat mengurangi stres

6. Permusuhan, kadang ada individu yang dengan mudah mengalami kemarahan dan permusuhan yang tinggi dengan individu yang lain. Individu yang seperti ini secara kronis mudah mencurigai dan tidak mudah percaya dengan orang lain.

Hasil penelitian Dumitru \& Cozman (2012) menunjukkan beberapa faktor kepribadian yang membuat individu menjadi lebih rentan terhadap stres saat dalam proses penyesuaian diri, antara lain: pemilihan teman, tingkat empati, kemandirian, penampilan, tingkat efisiensi intelektual, intuisi, orientasi kerja.

Chinaveh (2014) yang meneliti tentang tingkat stres pada siswa dengan tipe kepribadian $\mathrm{A}$ dan $\mathrm{B}$ sehubungan dengan respon mendekat dan menghindar, mendapatkan hasil bahwa perubahan stres diantara kepribadian tipe A dan B bevariasi sebagai fungsi dari respon coping individu. Hasil menujukkan efek utama yang signifikan untuk respon coping dan tidak ada efek utama yang signifikan pada perilaku tipe A-B. Hal ini menunjukkan bahwa ket- rampilan coping stres seseorang menjadi aspek yang lebih mempengaruhi dibandingkan dengan tipe kepribadian A dan B.

Menurut Lazarus dan Folkman (1984), coping berfungsi untuk mengubah situasi yang menyebabkan timbulnya stres atau mengatur reaksi emosional yang muncul karena suatu masalah. Mekanisme coping juga diklasifikasikan menjadi dua kategori (dalam Niven, 1995): tindakan langsung dan tindakan paliatif. Tindakan langsung termasuk "serangan" terhadap stimulus yang mengakibatkan stres itu sendiri dengan tujuan secara langsung mencoba mengurangi atau menghilangkan sumber stres. Dalam banyak keadaan coping tindakan langsung mungkin terlalu berat untuk orang-orang dan satu-satunya alternatif yang tersedia adalah mengubah respon internal mereka terhadap ancaman. Ancaman dari stressor dapat dikurangi dengan melarikan diri atau melibatkan diri dalam latihan relaksasi.

Temuan lain dalam analisis data menunjukkan bahwa bahwa tipe kepribadian B2 memiliki rentang skor stres antara 13-24; tipe kepribadian $\mathrm{AB}$ memiliki rentang skor stres antara 5-30; tipe kepribadian A2 memiliki rentang skor stres antara 4-29; dan tipe kepribadian A1 memiliki rentang skor stres antara 23-30. Hal ini menunjukkan bahwa kepribadan B2 memiliki rentang tingkat stres yang sedang hingga tinggi. Kepribadian $\mathrm{AB}$ dan kepribadian A2 memiliki rentang yang paling bervariasi dari ringan hingga tinggi, dan Kepribadian A1 memiliki miliki tingkat stres yang tinggi. Hal ini menunjukkan bahwa stres yang tinggi dialami oleh individu dengan kepribadian A dengan pola perilaku tipe A yang tinggi. Sedangkan pada tipe kepribadian yang lain tidak menunjukkan perbedaan yang signifikan pada tingkat stres.

Ada dua karakteristik pokok individu tipe A: time-urgency dan hostility (dalam Patel, 1989). Keduanya berdasarkan hipotesis yang diajukan oleh Friedman dan Rosenman. Time-urgency merupakan perasaan dimana individu merasa kekurangan waktu untuk melakukan semua hal yang dipercaya harus diselesaikan atau diharapkan dapat diselesaikan. Hostility (sikap permusuhan) yakni kecenderungan yang bertahan lama untuk mengevaluasi seseorang atau kejadian secara negatif, seringkali merasa curiga, sinis dan paranoid, kemarahan merupakan gabungan emosi yang kompleks berkisar dari kejengkelan, kegusaran, hingga kegeraman atau kemarahan. Kedua aspek tersebut dapat menyebabkan seseorang mempersepsi berlebihan terhadap stressor sehingga dapat mening- 
katkan stres.

\section{Pembahasan}

Pada penelitian ini menunjukkan bahwa level stres yang tinggi terlihat pada seseorang yang memiliki pola kepribadian tipe A yang tinggi juga (tipe A1). Akan tetapi, pada tipe kepribadian yang lain $(\mathrm{A} 2, \mathrm{AB}, \mathrm{B} 2)$ tidak ada perbedaan yang signifikan karena rentangnya tingkat stresnya beragam. Hal ini menghasilkan analisis statistik yang menunjukkan bahwa tidak ada perbedaan yang signifikan dalam tingkat stres warga Malang yang datang di CFD jika ditinjau dari tipe kepribadian A dan B.

Tidak ada keberbedaan tingkat stres berdasarkan pola kepribiadan A dan B ini, dapat sebabkan karena ada beberapa faktor lain yang memiliki andil lebih besar dalam menentukan tingkat stres. Faktor kemampuan individu mempersepsi stressor (dalam Perwitasari dkk, 2016) dan bagaimana kemampuan coping stres individu (mengubah situasi yang menyebabkan timbulnya stres atau mengatur reaksi emosional yang muncul) menjadi faktor yang lebih dominan dalam menentukan tingkat stres seseorang (dalam Chinaveh, 2014).

Kelemahan dalam penelitian ini dapat dimungkinkan karena tidak mempertimbangkan faktor yang turut andil dalam mempengaruhi tingkat stres seseorang. Dari kelemahan tersebut, dapat menjadi masukan bagi peneliti selanjutnya yang tertarik tentang tema stes atau kepribadian, untuk turut mempertimbangkan aspek lain.

\section{KESIMPULAN DAN SARAN}

\section{Kesimpulan}

Dalam penelitian dapat simpulkan bahwa tidak ada perbedaan yang signifikan dalam tingkat stres warga Malang yang datang di CFD jika ditinjau dari tipe kepribadian A dan B, karena ada beberapa faktor lain yang memiliki andil lebih besar dalam menentukan tingkat stres. Faktor kemampuan individu mempersepsi stressor dan bagaimana kemampuan coping stres individu (mengubah situasi yang menyebabkan timbulnya stres atau mengatur reaksi emosional yang muncul) menjadi faktor yang lebih dominan dalam menentukan tingkat stres seseorang.

Stres yang tinggi dialami oleh individu dengan kepribadian A dengan pola perilaku tipe A yang tinggi (tipe A1), sedangkan pada tipe kepribadian yang lain (A2, AB, B2) tidak ada perbedaan yang signifikan karena rentangnya tingkat stresnya beragam. Koresponden tipe kepribadian A1 memiliki jumlah yang paling sedikit, yaitu 2 orang. Hal ini menunjukkan bahwa orang-orang tipe kepribadian A yang ekstrim tidak menyukai kegiatan-kegiatan yang membuang-buang waktu seperti berjalan- jalan ke CFD. Mereka menyukai pergerakan yang cepat dan tidak sabaran. Mereka juga tipe orang yang akan sulit untuk duduk-duduk santai atau tidak melakukan apa-apa, karena mereka akan merasa bersalah saat beristirahat.

Orang yang memiliki tingkat stres yang sedang dan tinggi saja yang datang ke CFD, tetapi juga orang yang tingkat stres rendah atau tidak mengalami stres juga memilih untuk datang ke CFD

\section{Saran}

Untuk menurunkan stres, individu dapat mulai belajar untuk melatih bagaimana mengubah pandangan terhadap stressor menjadi sesuatu yang dapat membangun pribadi bukan menjadi sebuah ancaman. Meningkatkan kemampuan coping stres dengan mempelajari hal baru yang dapat mengatasi stres seperti relaksasi atau memperlajari skill baru yang dapat membantu individu untuk menyelesaikan masalah yang menyebabkan stres.

Peneliti berikutnya yang tertarik ingin meneliti stres dan kepribadian dapat menggunakan teori kerpibadian yang lain atau menambah variabel lain seperti coping stres atau persepsi subyek terhadap stres.

\section{REFERENSI}

Atkinson, R L., Atkinson, R C., Smith, E E. \& Bem, D J. (2010). Pengantar Psikologi Jilid Dua. Tangerang: Interkasara Publisher

Asih,Pribadi. (2015). Pengaruh Kepribadian dan Stres Kerja terhadap Kinerja Pegawai Sekolah Tinggi PenerbanganIndonesia (STPI) Curug- Tangerang. Jurnal Ilmiah Aviasi Langit Biru. Vol.10 No.1. Februari 2015.

Badeni. (2013). Kepemimpinan dan perilaku organisasi. Bandung: Alfabeta.

Baharudin, Fauziah Nuraini Kurdi, Andrias Lionardo. (2015). Analisis Perbedaan Tipe Kepribadian A dan B terhadap Managemen Konflik Interpersonal Pegawai Rumah Sakit Khusus Mata Provinsi Sumatra Selatan. PSIKIS- Jurnal Psikologi Islami Vol.1 No.2 (2015). 
Chinaveh, Mahbobeh. (2014). A comparison of Type-A and Type-B in perception of stress level and use of coping responses in Campus. Procedio- Social and Behavioral Sciences 143 (2014) 384-288

Dumitru, Voichita M. \& Cozman, Doina. (2012). The Relationship between Stress and Personality Factors. Human $\mathcal{E}$ Veterinary Medicine, International Journal of the Bioflux Society. Vol.4 Issue 1 (http://www.hvm.bioflux. com.ro/)

Lazarus, Richard S. \& Folkman, Susan. (1984). Stress, Appraisal, and Coping. New York: Springer Publishing Company

Migo, Y. D. (2013). Pengaruh Kepribadian, Budaya Organisasi dan Iklim Organisasi terhadap Stres Kerja di Kap Padang dan Pekan Baru. Jurnal Ilmiah Vol 2, No 1.

Nevid, Jeffrey S, Spencer A. Rathus \& Beverly Greene. 2003. Psikologi Abnormal Jilid 1. Jakarta : Erlangga.

Niven, Neil. (1995). Psikologi Kesehatan Pengantar untuk Perawat \& Profesional Kesehatan Lain. Jakarta: Penerbit Buku Kedokteran EGC.

Nuzulawati, Mety Tri. (2016). Hubungan antara Kepribadian tipe A dengan Stres Kerja pada Guru SMK Muhammadiyah Tegal. Jurnal Ilmiah Proyeksi, Vol.11 (1) 2016, 15-23.

Patel, Chandra. (1989). The Complete Guide to Stress Management. London: Vermilion Perwitasari, Dwi Tirta \& Nurbeti,

Novie \& Armyanti, Ita. (2016). Faktor- faktor yang Mempengaruhi Tingkatan Stres pada Tenaga Kesehatan di RS Universitas Tanjungpura Pontianak Tahun 2015. Jurnal erebellum. Vol.2 No.3. Agustus 2016

Santrock, John W (2003). Adolescence.Perkembangan Remaja. Edisi Keenam. Jakarta: Erlangga.

Sarafino, Edward P. (2007). Health Psychology Biopsychosocial Interactions Sixth Edition.

New Jersey: John Wiley \& Sons,Inc

Wijono, Sutarjo. 2006. Pengaruh Kepribadian type A dan Peran terhadap Stres Kerja Manager Madya. Insan Vol.8 No.3, Desember 2006.

http://profilkotamalang.blogspot.com/

http://eprints.umm.ac.id/35940/4/jiptumm pp-gdl-dessywulan-49637-4- babiii.pdf 